\title{
POLITIK HUKUM DALAM UPAYA PENGENDALIAN PENCEMARAN BAHAN BERBAHAYA DAN BERACUN DI WILAYAH LAUT YANG BERADA DIBAWAH KEDAULATAN INDONESIA
}

\author{
Adil Lugianto ${ }^{1}$, Arief Hidayat ${ }^{2}$
}

\begin{abstract}
Abstrak
Indonesia merupakan negara maritim sekaligus negara kepulauan. Indonesia memiliki sekitar 13. 487 pulau yang tersebar diseluruh nusantara, dimana setiap pulau tersebut dikelilingi perairan/laut. Indonesia terletak diantara dua benua yaitu benua asia dan Australia serta berada diantara dua samudera, yaitu samudera hindia dan samudera pasifik. Sebagian besar wilayah Indonesia terdiri dari wilayah laut/perairan yang mencakupi enam puluh persen (60\%) dari seluruh wilayah Indonesia dan sisanya sebesar empat puluh persen (40\%) adalah wilayah daratanKondisi geografis Indonesia yang sangat strategis tersebut berpotensi mendatangkan pencemaran, khususnya pencemaran bahan berbahaya dan beracun sehingga lingkungan/wilayah laut Indonesia perlu mendapat perlindungan dari pencemaran.
\end{abstract}

Permasalahan yang dibahas dalam penelitian ini antara lain: (1) Bagaimana kebijakan (policy) yang terdapat dalam instrumen-instrumen hukum internasional dalam upaya pengendalian pencemaran bahan berbahaya dan beracun di wilayah laut? (2) Bagaimana Politik Hukum dalam upaya pengendalian pencemaran bahan berbahaya dan beracun di wilayah laut yang berada dibawah kedaulatan Indonesia? (3) Bagaimana konsistensi dan harmonisasi secara vertikal maupun horizontal antar produk hukum yang mengatur tentang pencemaran bahan berbahaya dan beracun di wilayah laut yang berada dibawah kedaulatan Indonesia?

Penelitian ini menggunakan metode pendekatan yuridis normatif dengan spesifikasi penelitian deskriptif analisia. Data yang digunakan dalam penelitian ini adalah data sekunder yang dikumpulkan melalui studi kepustakaan. Data yang terkumpul dianalisis menggunakan metode kualitatif. Kebijakan (policy) dalam instrumen-instrumen hukum internasional mengatur upaya-upaya pencegahan terjadinya pencemaran bahan berbahaya dan beracun di wilayah laut/perairan, Politik hukum dalam perundang-undangan nasional mengatur pencegahan dan penanggulangan pencemaran bahan berbahaya dan beracun di wilayah laut/perairan

\footnotetext{
${ }^{1}$ Mahasiswa Program Studi Magister IImu Hukum

${ }^{2}$ Dosen Program Studi Magister IImu Hukum Undip
} 
dari aspek hukum administrasi, hukum perdata dan hukum pidana. Politik hukum yang terdapat dalam produk-produk hukum, baik secara vertikal maupun horizontal mengatur pengendalian pencemaran bahan berbahaya dan beracun di wilayah laut/perairan secara berbeda-beda, sehingga terjadi inkonsistensi dan disharmonisasi antar produk hukum tersebut.

Kata kunci: politik hukum, pencemaran, bahan berbahaya dan beracun, dan wilayah laut yang berada dibawah kedaulatan Indonesia.

\section{A. PENDAHULUAN}

1. Latar belakang

Lingkungan hidup merupakan karunia dan rahmat dari Tuhan Yang Mahan Esa untuk kesejahteraan umat manusia. Tuhan menciptakan bumi, daratan, lautan dan udara beserta seluruh isinya untuk dapat dikelola, dimanfaatkan, dilestarikan oleh manusia demi kesejahteraan hidup bersama. Oleh sebab itu, manusia dan lingkungan hidup memiliki hubungan yang sangat erat, sebagai hubungan yang saling membutuhkan dan mempengaruhi antar satu sama lainnya.

Perlindungan dan pengelolaan lingkungan hidup adalah upaya sistematis dan terpadu yang dilakukan untuk melestarikan fungsi lingkungan hidup dan mencegah terjadinya pencemaran dan/atau kerusakan lingkungan hidup yang meliputi perencanaan, pemanfaatan, pengendalian, pemeliharaan, pengawasan, dan penegakan hukum. ${ }^{3}$

Pencemaran lingkungan adalah setiap pembuangan bahan atau energi ke dalam air, tanah, atau udara yang menyebabkan atau dapat menyebabkan akut (jangka pendek) atau kronis (jangka panjang) kerugian bagi keseimbangan ekologi bumi atau yang menurunkan kualitas hidup. Polutan dapat menyebabkan

3 Pasal 1 ayat (2) Undang-Undang Republik Indonesia Nomor 32 tahun 2009 tentang Perlindungan dan Pengelolaan Lingkungan Hidup 
kerusakan primer, dengan dampak yang dapat diidentifikasi langsung terhadap lingkungan, atau kerusakan sekunder dalam bentuk gangguan kecil dalam keseimbangan rantai makanan biologis yang terdeteksi hanya selama jangka waktu lama. Jenisjenis pencemaran lingkungan hidup terdiri dari pencemaran air, pencemaran panas, pencemaran tanah, pencemaran yang disebabkan pestisida, pencemaran akibat radiasi, pencemaran suara dan pencemaran udara.

Berdasarkan Undang-Undang Nomor 32 tahun 2009 tentang Perlindungan dan Pengelolan Lingkungan Hidup (selanjutnya disebut UULH), Pencemaran lingkungan hidup adalah masuk atau dimasukkannya makhluk hidup, zat, energi, dan/atau komponen lain ke dalam lingkungan hidup oleh kegiatan manusia sehingga melampaui baku mutu lingkungan hidup yang telah ditetapkan. ${ }^{4}$ Baku mutu lingkungan hidup adalah ukuran yang digunakan untuk menentukan terjadinya pencemaran lingkungan hidup. ${ }^{5}$

Perlindungan dan pengelolaan lingkungan hidup dalam upaya menanggulangi pencemaran dilaksanakan berdasarkan asas: tanggungjawab negara, kelestarian dan keberlanjutan, keserasian dan keseimbangan, keterpaduan, manfaat, kehati-hatian, keadilan, ekoregion, keanekaragaman hayati, pencemar membayar, partisipatif, kearifan lokal, tatakelola pemerintahan yang baik dan otonomi daerah. $^{6}$

Indonesia merupakan negara maritim sekaligus negara kepulauan, sebagian besar wilayah Indonesia terdiri dari wilayah laut/perairan yang mencakupi enam puluh persen (60\%) dari seluruh wilayah Indonesia dan sisanya sebesar empat puluh

4 Pasal 1 ayat (14) Undang-Undang Republik Indonesia Nomor 32 tahun 2009 tentang Perlindungan dan Pengelolaan Lingkungan Hidup.

5 Pasal 1 ayat (13) Undang-Undang Republik Indonesia Nomor 32 tahun 2009 tentang Perlindungan dan Pengelolaan Lingkungan Hidup.

${ }^{6}$ Pasal 2 Undang-Undang Republik Indonesia Nomor 32 tahun 2009 tentang Perlindungan dan Pengelolaan Lingkungan Hidup. 
persen $(40 \%)$ adalah wilayah daratan. Indonesia memiliki sekitar 13. 487 pulau tersebar diseluruh nusantara, dimana setiap pulau tersebut dikelilingi perairan/laut. Indonesia terletak diantara dua benua yaitu benua asia dan Australia serta berada diantara dua samudera, yaitu samudera hindia dan samudera pasifik. Kondisi geografis tersebut menjadikan Indonesia sebagai negara yang sangat startegis, sebagai jalur perdagangan dunia yang dilintasi oleh jutaan kapal setiap tahun. Kondisi ini berpotensi mendatangkan pencemaran, sehingga lingkungan/wilayah laut Indonesia perlu mendapat perlindungan dari pencemaran.

Pencemaran dilingkungan/wilayah laut disebabkan oleh empat sumber yaitu: pencemaran dari kapal, dumping, aktivitas dasar laut dan aktivitas dari daratan. ${ }^{7}$ Pencemaran dari kapal berasal dari operasional kapal, pembuangan sampah/limbah secara langsung ke dalam laut dan pencemaran yang berasal dari barang/material kargo yang dibawa kapal. Dumping menjadi cara yang popular dalam membuang limbah yang bersumber dari aktivitas daratan ke dalam laut karena murah dan mudah dilakukan, sehingga tidak diperlukan pengelolaan limbah. Pencemaran yang bersumber dari aktivitas dasar laut, berasal dari hasil kegiatan eksplorasi dan eksploitasi minyak dan gas di dasar laut. Pencemaran yang bersumber dari aktivitas daratan umumnya berasal dari pembuangan limbah industri ke dalam laut dan penggunaan pestisida dan pupuk yang berlebihan dalam pertanian yang mengakibatkan pencemaran air tanah dan air laut.

Salah satu pencemaran di lingkungan/wilayah laut yang sangat berbahaya adalah pencemaran bahan berbahaya dan beracun (selanjutnya disebut Pencemaran B3). Pencemaran B3 adalah pencemaran yang disebabkan oleh zat, energi, dan/atau

\footnotetext{
${ }^{7}$ R.R. Churcil and A.V. Lowe, The Law of The Sea, Manchester: Manchester University Press, 1999, hlm. 329
} 
komponen lain yang karena sifat, konsentrasi, dan/atau jumlahnya, baik secara langsung maupun tidak langsung, dapat mencemarkan dan/atau merusak lingkungan hidup, dan/atau membahayakan lingkungan hidup, kesehatan, serta kelangsungan hidup manusia dan makhluk hidup lain. ${ }^{8}$

Usaha untuk meraih kesuksesan dalam penanggulangan pencemaran B3 di lingkungan/wilayah laut di Indonesia memerlukan suatu politik hukum sebagai kebijakan dasar untuk menentukan arah, bentuk, maupun isi hukum dalam menanggulangi pencemaran B3 tersebut. Dalam melaksanakan politik hukum, harus disadari bahwa banyak faktor yang mempengaruhinya, tidak hanya faktor masyarakat yang bagaimana akan kita bangun atau cita-citakan, atau hanya tergantung pada kehendak pembentuk undang-undang saja, atau lembaga yang diberi wewenang menciptakan undang-undang, tetapi juga dipengaruhi oleh realitas social dan tradisi-tradisi yang terdapat dalam masyarakat Indonesia serta realita yang berkembang didunia internasional, mengingat Indonesia sebagai salah satu anggota masyarakat dari masyarakat dunia.

Politik hukum memberikan penjelasan bagaimana sebaiknya hukum dibentuk sesuai dengan tujuan negara dan perkembanganperkembangan dunia internasional. Politik hukum menitik beratkan pada kebijakan yang akan ditempuh dalam mengadakan pembaharuan hukum serta perubahan-perubahan yang harus dilakukan terhadap lembaga hukum (perundang-undangan dengan segala aspek yang ada) guna menyesuaikan diri dengan perkembangan dunia di era globalisasin ini. ${ }^{9}$

8 Lihat pengertian Bahan Berbahaya dan Beracun dalam pasal 1 ayat (21) Undang-Undang Republik Indonesia Nomor 32 tahun 2009 tentang Perlindungan dan Pengelolaan Lingkungan Hidup.

9 Nyoman Serikat Putera Jaya, Politik Hukum, Semarang: Badan Penyediaan Bahan Kuliah Program Studi Magister Kenotariatan Universitas Diponegoro, hlm. 10. 
Berdasarkan pandangan politik hukum tersebut diatas, maka seyogianya upaya penanggulangan pencemaran B3 di lingkungan/wilayah laut Indonesia disusun dan dilakukan dalam suatu politik hukum yang memperhatikan ketentuan-ketentuan internasional yang berkaitan dengan pencemaran B3 di lingkungan/wilayah laut, selain cita hukum dan fakta-fakta pencemaran B3 di lingkungan/wilayah laut Indonesia. Bertitik tolak dari berbagai landasan tersebut diatas, penulis tertarik menulis tesis dengan judul "Politik Hukum Dalam Upaya Pengendalian Pencemaran Bahan Berbahaya dan Beracun Di Wilayah Laut Yang Berada Di bawah Kedaulatan Indonesia".

2. Permasalahan

Berdasarkan latar belakang masalah yang telah dikemukakan diatas, penulis merumuskan permasalahan yang akan dibahas dalam tesis ini sebagai berikut:

1) Bagaimana kebijakan (policy) yang terdapat dalam instrumeninstrumen hukum internasional dalam upaya penanggulangan pencemaran bahan berbahaya dan beracun di wilayah laut?

2) Bagaimana Politik Hukum dalam upaya pengendalian pencemaran bahan berbahaya dan beracun di wilayah laut yang berada dibawah kedaulatan Indonesia?

3) Bagaimana konsistensi dan harmonisasi secara vertikal maupun horizontal antar produk hukum yang mengatur tentang pencemaran bahan berbahaya dan beracun di wilayah laut yang berada dibawah kedaulatan Indonesia?

3. Tujuan Penelitian

Berdasarkan uraian latar belakang dan rumusan masalah tersebut di atas, adapun tujuan dari penulisan ini yaitu: 
1) Untuk mengetahui bagaimana kebijakan dalam instrumeninstrumen hukum internasional dalam upaya penanggulangan pencemaran bahan berbahaya dan beracun di wilayah laut.

2) Untuk mengetahui bagaimana Politik Hukum dalam upaya penanggulangan pencemaran bahan berbahaya dan beracun di laut Indonesia.

3) Untuk mengetahui ada atau tidaknya inkonsistensi dan disharmonisasi secara vertikal maupun horizontal antar produk hukum yang mengatur tentang pencemaran bahan berbahaya dan beracun di wilayah laut Indonesia.

4. Tinjauan Pustaka

Politik hukum sampai saat ini belum memiliki satu pengertian/definisi yang baku. Secara etimologis, istilah politik hukum merupakan terjemahan bahasa Indonesia dari istilah hukum Belanda rechtspolitiek yang merupakan bentukan dari dua kata recht dan politiek. Dalam bahasa Indonesia recht berarti hukum. Adapun dalam kamus bahasa Belanda yang ditulis oleh van der tas, kata politiek mengandung arti beleid. Kata beleid sendiri dalam bahasa Indonesia berarti kebijakan (policy). Dari penjelasan itu bisa dikatakan bahwa politik hukum secara singkat berarti kebijakan hukum. Dengan kata lain, politik hukum adalah rangkaian konsep dan asas yang menjadi garis besar dan dasar rencana dalam pelaksanaan suatu pekerjaan, kepemimpinan dan cara bertindak dalam bidang hukum. ${ }^{10}$

Ciri-ciri politik hukum yang baik dapat dilihat dari konsistensi dan harmonisasi baik secara vertikal maupun horizontal antar produk hukum yang dibentuk, sehingga tidak terjadi pertentangan

${ }^{10}$ Imam Syaukani dan A. Ahsin Thohari, Dasar-Dasar Politik Hukum, Jakarta: Rajawali Pers, 2004, halaman 19-22. 
antar produk hukum itu sendiri baik secara vertikal maupun horizontal. Jenis dan hierarki peraturan perundang-undangan terdiri atas: ${ }^{11}$

a. Undang-Undang Dasar Negara Republik Indonesia Tahun 1945;

b. Ketetapan Majelis Permusyawaratan Rakyat;

c. Undang/Undang atau Peraturan Pemerintah Pengganti UndangUndang;

d. Peraturan Pemerintah;

e. Peraturan Presiden;

f. Peraturan Daerah provinsi; dan

g. Peraturan Daerah Kabupaten/Kota.

Politik hukum dasar mengenai lingkungan hidup di Indonesia dapat ditemukan dalam Undang-Undang Dasar Negara Republik Indonesia Tahun 1945 (Konstitusi RI). Politik hukum tersebut ditemukan dalam Pasal $28 \mathrm{H}$ ayat (1) menyatakan bahwa "Setiap orang berhak hidup sejahtera lahir dan batin, bertempat tinggal, dan mendapatkan lingkungan hidup yang baik dan sehat serta berhak memperoleh pelayanan kesehatan", Pasal 33 ayat (3) menyatakan bahwa "Bumi dan air dan kekayaan alam yang terkandung didalamnya dikuasai oleh negara dan dipergunakan untuk sebesar-besarnya kemakmuran rakyat", dan Pasal 33 ayat (4) "Perekonomian nasional diselenggarakan berdasar atas demokrasi ekonomi dengan prinsip kebersamaan, efisiensi berkeadilan, berkelanjutan, berwawasan lingkungan, kemandirian,

${ }^{11}$ Pasal 7 Undang-Undang Nomor 12 Tahun 2011 tentang Pembentukan Peraturan Perundangundangan. 
serta dengan menjaga keseimbangan kemajuan dan kesatuan ekonomi nasional".

Berdasarkan politik hukum dasar tersebut diatas dapat diambil kesimpulan bahwa lingkungan yang baik merupakan hak asasi bagi setiap manusia yang harus dilestarikan secara terus menurus oleh siapa saja baik negara yang diwakili pemerintah, sektor swasta maupun masyarakat itu sendiri. Lingkungan hidup (bumi, air dan kekayaan alam yang terkandung didalamnya) digunakan untuk sebesar-besarnya kemakmuran rakyat dan bukan milik perorangan ataupun golongan/kelompok masyarakat tertentu. Negara (pemerintah) memiliki hak dan wewenang menguasai dan mengelola lingkungan hidup tersebut untuk mewujudkan kemakmuran rakyat. Perekonomian nasional juga harus diselenggarakan berdasarkan wawasan lingkungan, dalam arti kegiatan perekonomian ikut berperan meningkatkan dan mempertahankan kelestarian fungsi lingkungan hidup, untuk mencapai kesejahteraan/kemakmuran hidup seluruh rakyat.

Bahaya pencemaran lingkungan mengancam kelestarian fungsi lingkungan hidup, sehingga usaha pemanfaatan lingkungan hidup untuk kesejahteraan/kemakmuran rakyat menjadi terhalang, bahkan negara dan rakyat menderita kerugian yang amat besar akibat pencemaran lingkungan hidup tersebut. Pencemaran lingkungan hidup adalah masuk atau dimasukkannya makhluk hidup, zat, energi, dan/atau komponen lain ke dalam lingkungan hidup oleh kegiatan manusia sehingga melampaui baku mutu lingkungan hidup yang telah ditetapkan. ${ }^{12}$

Salah satu pencemaran lingkungan hidup yang sangat berbahaya adalah pencemaran yang diakibatkan oleh B3. Hal ini

12 Pasal 1 ayat (14) Undang-Undang Republik Indonesia Nomor 32 tahun 2009 tentang Perlindungan dan Pengelolaan Lingkungan Hidup. 
disebabkan pencemaran akibat B3 mendatangan dampak yang lebih besar dan berbahaya terhadap lingkungan hidup dan masyarakat dibandingkan pencemaran lainnya. Pencemaran B3 adalah pencemaran yang disebabkan oleh zat, energi, dan/atau komponen lain yang karena sifat, konsentrasi, dan/atau jumlahnya, baik secara langsung maupun tidak langsung, dapat mencemarkan dan/atau merusak lingkungan hidup, dan/atau membahayakan lingkungan hidup, kesehatan, serta kelangsungan hidup manusia dan makhluk hidup lain. ${ }^{13}$

Indonesia sebagai negara maritim dan kepulauan memiliki wilayah laut yang sangat luas, melebihi luas wilayah daratan. Luas wilayah laut Indonesia ditetapkan dan diakui berdasarkan Konvensi Hukum Laut Internasional Tahun 1982 (United Nation Convention on Law of The Sea 1982), sebagaimana telah diratifikasi Indonesia melalui Undang-Undang Nomor 17 tahun 1985.

Perairan Indonesia meliputi laut teritorial Indonesia, perairan kepulauan, dan perairan pedalaman. Laut Teritorial Indonesia adalah jalur laut selebar 12 (dua belas) mil laut yang diukur dari garis pangkal kepulauan Indonesia. Perairan Kepulauan Indonesia adalah semua perairan yang terletak pada sisi dalam garis pangkal lurus kepulauan tanpa memperhatikan kedalaman atau jaraknya dari pantai. Perairan Pedalaman Indonesia adalah semua perairan yang terletak pada sisi darat dari garis air rendah dari pantai-pantai Indonesia, termasuk ke dalamnya semua bagian dari perairan yang terletak pada sisi darat dari suatu garis penutup.

Indonesia sebagai negara kepulauan berhak menarik garis pangkal kepulauan untuk menghubungkan titik-titik terluar pulau-

${ }^{13}$ Lihat pengertian Bahan Berbahaya dan Beracun dalam pasal 1 ayat (21) Undang-Undang Republik Indonesia Nomor 32 tahun 2009 tentang Perlindungan dan Pengelolaan Lingkungan Hidup. 
pulau dan karang kering terluar pulau itu, dimana panjang garis pangkal demikian tidak boleh melebihi 100 mil laut, kecuali bahwa hingga $3 \%$ dari jumlah seluruh garis pangkal yang mengelilingi setiap kepulauan dapat melebihi kepanjangan tersebut, hingga pada suatu kepanjangan maksimum 125 mil laut. Garis pangkal kepulauan menjadi patokan bagi Indonesia untuk mengukur lebar laut territorial. Perairan yang terletak pada sisi dalam garis pangkal lurus kepulauan adalah perairan kepulauan

Garis pangkal biasa adalah garis air rendah sepanjang pantai. Garis pangkal lurus adalah garis lurus yang menghubungkan titiktitik terluar pada garis pantai yang menjorok jauh dan menikung ke daratan atau deretan pulau yang terdapat di dekat sepanjang pantai. Perairan yang terletak pada sisi darat dari garis pangkal biasa dan garis pangkal lurus adalah perairan pedalaman.

Kedaulatan Negara Republik Indonesia di perairan Indonesia meliputi laut teritorial, perairan kepulauan, dan perairan pedalaman serta ruang udara di atas laut teritorial, perairan kepulauan, dan perairan pedalaman serta dasar laut dan tanah di bawahnya termasuk sumber kekayaan alam yang terkandung di dalamnya

Wilayah perairan Indonesia yang begitu luas selain memiliki kekayaan sumber daya alam laut yang sangat luar biasa, baik kekayaan sumber daya alam hayati maupun sumber daya alam non hayati, juga sangat rentan terhadap pencemaran, terutamanya pencemaran B3. Oleh sebab itu, politik hukum berperan penting merumuskan kebijakan-kebijakan untuk meraih kesuksesan dalam upaya penanggulangan pencemaran bahan berbahaya dan beracun di laut Indonesia.

\section{Metode Penelitian}


1) Metode Pendekatan

Metode pendekatan dalam rangka peninjauan terhadap kebijakan hukum ini dilakukan dengan pendekatan yuridis normatif. Pusat perhatian dalam penelitian ini ialah kebijakan dalam instrumen-instrumen hukum internasional dan politik hukum nasional dalam upaya penanggulangan pencemaran bahan berbahaya dan beracun di wilayah laut. Penelitian hukum dengan metode pendekatan yuridis normatif dilakukan dengan cara meneliti bahan pustaka dan data sekunder. ${ }^{14}$ Penelitian dengan menggunakan pendekatan yuridis normatif dilakukan dengan meneliti aspek-aspek hukum berupa peraturan perundang-undangan dan bahan hukum lainnya yang berkaitan dengan politik hukum dalam upaya penanggulangan pencemaran bahan berbahaya dan beracun.

2) Spesifikasi Penelitian

Spesifikasi yang digunakan dalam penelitian ini adalah deskriptif analisis. Menurut Ronny Hanitijo Soemitro, deskriptif analisis yaitu menggambarkan peraturan perundang-undangan yang berlaku dikaitkan dengan teori-teori hukum dan praktik pelaksaan hukum positif yang menyangkut permasalahan. Ciriciri metode deskriptif analisis yaitu: ${ }^{15}$

a. Memusatkan diri pada pemecahan masalah yang sedang diteliti dan dihubungkan dengan teori-teori hukum dan praktik pelaksanaan hukum positif yang menyangkut permasalahan yang sedang diteliti

\footnotetext{
14 Soerjono Soekanto dan Sri Mamudji, Penelitian Hukum Normatif, (Jakarta: Rajawali Pers, 2004), halaman 13.

${ }^{15}$ Surachmad Winarno, Dasar dan Teknik Research Pengantar Metodologi Ilmiah, (Bandung: CV Tarsito, 1970), halaman 135.
} 
b. Data yang dikumpulkan mula-mula disusun, dijelaskan dan kemudian dianalisa.

3) Jenis dan Sumber Data

Sehubungan dengan metode pendekatan dalam penelitian ini adalah yuridis normatif, maka penelitian ini dilakukan dengan studi pustaka yang bersumber pada data sekunder. Data sekunder memiliki ciri-ciri sebagai berikut: ${ }^{16}$

a. Data sekunder pada umumnya dalam keadaan siap terbuat (ready made);

b. Bentuk maupun isi data telah dibentuk dan diisi oleh peneliti terlebih dahulu;

c. Data sekunder dapat diperoleh tanpa terikat atau dibatasi oleh waktu dan tempat.

Data sekunder yang dikumpulkan dalam penelitian ini terdiri dari bahan hukum primer yaitu: peraturan perundangundangan, bahan hukum sekunder adalah bahan hukum yang diperoleh dari buku teks, jurnal, pendapat para sarjana, bahan seminar/simposium yang dilakukan oleh para pakar terkait dan bahan hukum tersier adalah bahan hukum yang memberikan petunjuk atau penjelasan bermakna terhadap bahan hukum primer dan sekunder, seperti kamus, ensiklopedia dan lain-lain.

4) Metode Pengumpulan data

Data sekunder yang merupakan sumber utama dalam penelitian ini dikumpulkan dengan melakukan studi kepustakaan/studi

${ }^{16}$ Soerjono Soekanto, Op. cit., halaman 28. 
dokumenter. Data Sekunder dapat diperoleh di perpustakaan, pusat dokumentasi, arsip dan museum. ${ }^{17}$ Dengan demikian studi ini untuk mencari konsepsi-konsepsi, teori-teori, pendapatpendapat dan penemuan-penemuan yang berhubungan dengan pokok permasalahan. ${ }^{18}$

5) Metode Analisis Data

Penelitian ini bersifat analisis kualitatif, yaitu menggambarkan, menjelaskan, serta menganalisis sejumlah data sekunder yang telah diperoleh. Penjelasan terhadap data dilakukan dengan menggunakan teori-teori dan norma-norma hukum yang ada, sedangkan keseluruhan data yang diperoleh disajikan secara kealitatif yaitu dalam bentuk uraian yang sistematis. ${ }^{19}$

B. HASIL PENELITIAN DAN PEMBAHASAN

1. KEBIJAKAN (POLICY) YANG TERDAPAT DALAM INSTRUMENINSTRUMEN HUKUM INTERNASIONAL DALAM UPAYA

\footnotetext{
17 Burhan Ashshofa, Metode Penelitian Hukum, (Jakarta: Rineka Cipta, 1996) halaman 104.

${ }^{18}$ Ronny Hanitijo Soemitro, Metode Penelitian Hukum dan Jumitri ( Jakarta: Ghalia Indonesia, 1990), halaman 98

${ }^{19}$ Soerjono Soekanto, Op. cit., halaman 250. 
PENGENDALIAN PENCEMARAN BAHAN BERBAHAYA DAN BERACUN DI WILAYAH LAUT.

a. Konvensi Internasional Tentang Pencegahan Pencemaran dari Kapal Tahun 1973

(i) Lampiran II (Pengendalian pencemaran oleh zat cair berbahaya).

Lampiran ini berisi rincian kriteria dan tindakan untuk kontrol pencemaran oleh zat cair berbahaya dilakukan dalam jumlah besar. Sekitar 250 zat dievaluasi dan termasuk dalam daftar zat cair berbahaya. Pembuangan mereka residu diperbolehkan hanya untuk fasilitas yang memadai sampai konsentrasi dan kondisi tertentu (yang bervariasi dengan kategori zat) dipenuhi. Dalam hal apapun, tidak ada pembuangan residu mengandung zat berbahaya yang diizinkan dalam waktu 12 mil dari terdekat tanah. Pembatasan yang lebih ketat diterapkan ke daerah Laut Baltik dan Hitam.

(ii) Lampiran III (Pencegahan pencemaran oleh zat-zat berbahaya dalam bentuk kemasan).

Lampiran III berisi persyaratan umum untuk dikeluarkannya standar rinci tentang kemasan, tanda, label, dokumentasi, penyimpanan, keterbatasan kuantitas, pengecualian dan pemberitahuan untuk mencegah polusi berbahaya oleh zat. Hal tersebut diatur dalam Ketentuan Barang Berbahaya Maritim Internasional (IMDG Code) sejak 1991, termasuk polusi laut. 
b. Konvensi Internasional tentang Keselamatan Kehidupan Laut Tahun 1974.

(i) Ketentuan Pengangkutan Barang Berbahaya (Bab VII A)

Bagian ini berlaku untuk pengangkutan barang berbahaya dalam bentuk kemasan di semua kapal yang peraturan ini berlaku dan dalam kapal kargo kurang dari 500 tonase kotor. Ketentuan-ketentuan bagian ini tidak berlaku untuk kapal penyimpan dan kapal peralatan.

(ii) Pengangkutan barang berbahaya dalam bentuk kemasan dilarang kecuali sesuai dengan ketentuan bab ini. Pengangkutan barang berbahaya dalam bentuk kemasan harus dalam Pemenuhan ketentuan yang relevan dalam ketentuan yang ditetapkan organisasi maritim internasional.

(iii) Kapal harus membawa dokumen lengkap berkaitan dengan identitas bahan berbahaya yang dibawa, berikut perizinannya.

(iv) Untuk melengkapi ketentuan-ketentuan bagian ini, setiap pihak Pemerintah menerbitkan, atau menyebabkan yang akan dikeluarkan, petunjuk rinci tentang tanggap darurat dan pertolongan pertama medis yang relevan untuk insiden yang melibatkan barang berbahaya dalam bentuk kemasan.

(v) Kargo unit kargo, kargo dan unit transportasi akan dimuat, disimpan dan dijamin sepanjang perjalanan berdasarkan ketentuan keselamatan kargo manual. 
(vi) Ketika sebuah insiden terjadi yang melibatkan kerugian atau hilangnya kemungkinan kapal barang berbahaya dalam bentuk kemasan ke laut, kapten kapal, atau orang lain yang memiliki muatan kapal, wajib melaporkan secara khusus mengenai insiden seperti itu tanpa penundaan dan ke semaksimal mungkin ke negara pantai terdekat. Laporan tersebut harus disusun berdasarkan prinsipprinsip umum dan pedoman yang dikembangkan oleh Organisasi. Dalam hal kapal ditinggalkan, atau dalam hal laporan dari seperti sebuah kapal yang tidak lengkap atau tidak dapat diperoleh, perusahaan berkewajiban memenuhi tanggungjawab tersebut.

c. Konvensi Perserikatan Bangsa-Bangsa tentang Hukum Laut Internasional 1982.

Konvensi tentang Hukum Laut Internasional disahkan pada tahun 1982 dalam siding umumPerserikatan Bangsa-Bangsa. Konvensi ini mulai berlaku tahun 1996 setelah diratifikasi 60 negara. Dalam konvensi ini Negara-negara harus mengambil tindakan untuk mencegah, mengurangi dan mengendalikan pencemaran lingkungan laut menggunakan cara yang paling praktis sesuai kemampuannya masing-masing dan menjamin agar kegiatan-kegiatan dibawah yuridiksi atau pengawasannya tidak mengakibatkan pencemaran dan menjamin pencemaran tersebut tidak menyebar melampaui daerah-daerah yang ada dibawah pelaksanaan hak-hak kedaulatannya. Tindakantindakan yang diambil direncanakan untuk mengurangi sejauh mungkin: $:^{20}$

${ }^{20}$ Pasal 194 Konvensi PBB tentang Hukum laut Internasional. 
(i) Dilepaskannya bahan-bahan yang beracun, berbahaya atau mengganggu, khususnya bahan-bahan yang persisten, yang berasal dari sumber daratan atau melalui udara atau karena dumping.

(ii) Pencemaran dari kendaraan air, terutama tindakan-tindakan untuk mencegah kecelakaan dan yang berkenaan dengan keadaan darurat, untuk menjamin keselamatan operasi di laut, untuk mencegah terjadinya pembuangan yang disengaja atau tidak serta mengatur desain, konstruksi, peralatan, operasi dan tata awak kendaraan air

(iii) Pencemaran dari instalasi-instalasi dan alat peralatan yang digunakan dalam eksplorasi atau eksploitasi kekayaan alam dasar laut dan tanah dibawahnya khususnya tindakantindakan untuk mencegah kecelakaan dan yang bertalian dengan keadaan darurat untuk menjamin keselamatan operasi di laut serta mengatur desain, konstruksi, peralatan, operasi dan tata awak instalasi-instalasi atau peralatan termaksud

(iv) Pencemaran dari lain-lain instalasi dan peralatan yang dioperasikan dalam lingkungan laut, terutama tindakantindakan untuk mencegah kecelakaan dan yang berkenaan dengan keadaan darurat, untuk menjamin keselamatan operasi di laut, mengatur desain, konstruksi, peralatan, operasi dan tata awak instalasi-instalasi atau peralatan termaksud.

2. POLITIK HUKUM DALAM UPAYA PENGENDALIAN PENCEMARAN BAHAN BERBAHAYA DAN BERACUN DI 
WILAYAH LAUT YANG BERADA DIBAWAH KEDAULATAN INDONESIA

a. Politik Hukum dalam Undang-Undang Nomor 32 Tahun 2009 tentang Perlindungan dan Pengelolaan Lingkungan Hidup (UUPPLH) Berkaitan Pengendalian Pencemaran Bahan Berbahaya dan Beracun di Wilayah Laut yang Berada dibawah Kedaulatan Indonesia.

Aspek hukum administrasi pengendalian pencemaran B3 di Wilayah Laut yang Berada dibawah Kedaulatan Indonesia dalam UUPPLH mencakup ketentuan mengenai Pengelolaan B3 dan Limbah B3, Penanggulangan dan Pemulihan Pencemaran B3, Larangan Memasukkan B3 dan limbah B3, Pengawasan B3, sanksi administratif bagi pemcemar B3 dan hak gugat pemerintah dan gugatan administratif berkaitan pencemaran B3.

Aspek hukum pengendalian pencemaran B3 di Wilayah Laut yang Berada dibawah Kedaulatan Indonesia mencakup penyelesaian sengketa diluar pengadilan, Ganti Kerugian Melalui Putusan Pengadilan, Tanggungjawab Mutlak dalam Pencemaran B3, Hak Gugat Masyarakat dan Organisasi Lingkungan Hidup.

Tindak Pidana Berkaitan Pencemaran B3 di Wilayah Laut yang Berada dibawah Kedaulatan Indonesia

(i) Tindak Pidana yang memasukkan limbah B3 ke dalam wilayah Negara Kesatuan Republik, baik wilayah daratan maupun laut (Pasal 106)

(ii) Tindak Pidana memasukkan B3 yang dilarang menurut peraturan perundang-undangan ke dalam wilayah Negara Kesatuan Republik Indonesia, baik wilayah daratan maupun laut (Pasal 107) 
(iii) Tindak Pidana melakukan pengelolaan B3 tanpa izin (Pasal 102)

(iv)Tindak Pidana menghasilkan B3 dan tidak melakukan pengelolaan (Pasal 103)

b. Politik Hukum Dalam Undang-Undang Nomor 17 Tahun 2008 tentang Pelayaran (UU Pelayaran) Berkaitan Pengendalian Pencemaran Bahan Berbahaya dan Beracun di Wilayah Laut yang Berada dibawah Kedaulatan Indonesia

Aspek hukum administrasi pengendalian pencemaran B3 di laut dalam UU pelayaran mencakup ketentuan mengenai Pengangkutan Barang Berbahaya, perlindungan lingkungan maritim, pencegahan pencemaran dari kapal, Penanggulangan Pencemaran Dari Kapal dan Manajemen Keselamatan dan pencegahan pencemaran dari Kapal, dan sanksi administratif bagi pelanggar ketentuan tersebut.

UU Pelayaran tidak mengatur berkaitan penyelesaian sengketa perdata berkaitan dengan pencemaran B3, seperti: ganti rugi dan gugatan. Meskipun demikian, penyelesaian sengketa perdata pencemaran B3 berkaitan dengan pelayaran dapat menggunakan mekanisme penyelesaian sengketa dalam UUPPLH sebagaimana telah diuraikan di atas sepanjang ada kaitannya dengan pelayaran

Mekanisme hukum perdata dalam Kitab Undang-Undang Perdata juga dapat digunakan dalam hal menuntut ganti kerugian berhubung dengan penderitaan akibat pencemaran 
B3 sesuai dengan ketentuan perbuatan melawan hukum dalam Pasal 1365 KUH Perdata yang menyatakan: Tiap perbuatan melanggar hukum yang membawa kerugian kepada seseorang atau orang lain, mewajibkan orang yang karena salahnya menerbitkan kerugian itu, mengganti kerugian tersebut.

Tindak Pidana Berkaitan Pencemaran B3 di Wilayah Laut yang Berada dibawah Kedaulatan Indonesia

(i) Tindak pidana mengangkut barang berbahaya yang tidak memenuhi persyaratan (Pasal 294)

(ii)Tindak Pidana mengakut barang berbahaya tidak menyampaikan pemberitahuan kepada syahbandar (Pasal 295)

(iii)Tindak Pidana tidak melakukan pencegahan dan penanggulangan terhadap terjadinya pencemaran lingkungan yang bersumber dari kapal (Pasal 324)

(iv) Tindak pidana melakukan pembuangan limbah air balas, kotoran, sampah atau bahan lain ke perairan (Pasal 325)

(v) Tindak pidana tidak mengasuransikan tanggungjawabnya terhadap pencemaran yang bersumber dari kapalnya (Pasal 327)

c. Politik Hukum Dalam Undang-Undang Nomor 6 Tahun 1996 tentang Perairan Indonesia Berkaitan Pengendalian Pencemaran Bahan Berbahaya dan Beracun di Wilayah Laut yang Berada dibawah Kedaulatan Indonesia.

Perlindungan dan pelestarian lingkungan perairan Indonesia, termasuk perlindungan dan pelestarian lingkungan perairan dari pencemaran B3 dilakukan berdasarkan peraturan perundang-undangan nasional yang berlaku dan hukum 
internasional. ${ }^{21}$ Penegakan kedaulatan dan hukum di perairan Indonesia, ruang udara di atasnya, dasar laut dan tanah di bawahnya termasuk kekayaan alam yang terkandung di dalamnya serta sanksi atas pelang-garannya, dilaksanakan sesuai dengan ketentuan Konvensi hukum internasional lainnya, dan peraturan perundang-undangan yang berlaku. ${ }^{22}$

Instrumen-instrumen hukum internasional berkaitan pengendalian pencemaran bahan berbahaya dan beracun di laut yang telah diratifikasi Indonesia sebagaimana diuraikan di atas antara lain: Konvensi Internasional Tentang Pencegahan Pencemaran dari Kapal Tahun 1973, Konvensi Internasional tentang Keselamatan Kehidupan Laut 1974, Konvensi Perserikatan Bangsa-Bangsa tentang Hukum Laut Internasional 1982. Peraturan perundang-undangan Indonesia berkaitan pengendalian pencemaran bahan berbahaya dan beracun di laut Indonesia sebagaimana diuraikan di atas antara lain Undang-Undang Nomor 32 Tahun 2009 tentang Perlindungan dan Pengelolaan Lingkungan hidup dan Undang-Undang Nomor 17 Tahun 2008 tentang Pelayaran. Dengan demikian, perlindungan dan pelestarian lingkungan perairan dari pencemaran B3, baik dari aspek hukum administrasi, hukum perdata maupun hukum pidana dilakukan berdasarkan konvensi-konvensi dan undang-undang tersebut di atas.

d. Politik Hukum dalam Peraturan Pemerintah Nomor 74 Tahun 2001 tentang Pengeloaan Bahan Berbahaya dan Beracun (PPPB3) Berkaitan Pengendalian Pencemaran Bahan

\footnotetext{
${ }^{21}$ Pasal 23 Undang-Undang Nomor 6 Tahun 1996 tentang Perairan Indonesia

${ }^{22}$ Pasal 24 Undang-Undang Nomor 6 Tahun 1996 tentang Perairan Indonesia
} 
Berbahaya dan Beracun di Wilayah Laut yang Berada dibawah Kedaulatan Indonesia.

Aspek hukum administrasi dalam pembahasan ini mencakup registrasi B3, notifikasi B3, Pengemasan B3, penyimpanan B3, Pengangkutan B3 di wilayah laut yang berada dibawah kedaulatan Indonesia, Penanggulangan Kecelakaan dan Tanggap Darurat, Pengawasan B3 beserta sanksi administratifnya bagi pencemar di wilayah laut yang berada dibawah kedaulatan Indonesia.

Aspek hukum perdata dalam pembahasan ini mencakup ganti kerugian, tanggungjawab mutlak, dan pembebasan tanggungjawab dalam pencemaran B3 di wilayah laut yang berada dibawah kedaulatan Indonesia

Setiap orang yang melanggar ketentuan pengelolaan B3 dalam PPPB3 yang mengakibatkan terjadinya pencemaran dan atau perusakan lingkungan hidup dapat dijatuhi pidana berdasarkan ketentuan dalam undang-undang lingkungan hidup.

e. Politik Hukum dalam Peraturan Pemerintah Nomor 19 Tahun 1999 tentang Pengendalian Pencemaran dan/atau Perusakan Laut (P5L) Berkaitan Pengendalian Pencemaran Bahan Berbahaya dan Beracun di Wilayah Laut yang Berada dibawah Kedaulatan Indonesia.

Aspek hukum administrasi dalam pembahasan ini mencakup pencegahan pencemaran, penanggulangan pencemaran dan pengawasan pencemaran B3 di wilayah laut yang berada dibawah kedaulatan Indonesia. 
Setiap orang atau penanggung jawab usaha dan/atau kegiatan yang mengakibatkan pencemaran di wilayah laut yang berada dibawah kedaulatan indonesia wajib menanggung biaya penanggulangan pencemaran serta biaya pemulihannya atau menimbulkan kerugian bagi pihak lain, akibat terjadinya pencemaran di wilayah laut yang berada dibawah kedaulatan indonesia wajib membayar ganti rugi terhadap pihak yang dirugikan $^{23}$

3. KONSISTENSI DAN HARMONISASI SECARA VERTIKAL DAN HORIZONTAL ANTAR PRODUK HUKUM YANG MENGATUR PENGENDALIAN PENCEMARAN BAHAN BERBAHAYA DAN BERACUN DI WILAYAH LAUT YANG BERADA DIBAWAH KEDAULATAN INDONESIA

Berdasarkan uraian di atas, dapat disimpulkan bahwa terjadi inkonsistensi antara politik hukum ideal (pancasila) dengan politik hukum yang terdapat dalam undang-undang yang mengatur pengendalian pencemaran bahan berbahaya dan beracun di wilayah laut Indonesia karena nilai-nilai pancasila sila pertama (ketuhanan), sila kedua (kemanusiaan) dan sila ketiga (persatuan) tidak diterjemahkan ke dalam pengendalian pencemarab B3 di laut Indonesia dan hanya sila keempat (kerakyatan/demokrasi) dan sila ke lima (keadilan sosial) yang diterjemahkan dalam politik hukum tersebut, sehingga mengakibatkan terjadinya ketidaktetapan, ketidakselarasan, ketidaksesuaian, ketidakserasian, ketidakcocokan dan ketidakseimbangan antara politik hukum ideal (pancasila) dengan politik hukum yang terdapat dalam undang-

23 Pasal 24 Peraturan pemerintah Nomor 19 Tahun 1999 tentang Pengendalian Pencemaran/Perusakan Lingkungan Laut 
undang yang mengatur pengendalian pencemaran bahan berbahaya dan beracun di wilayah laut Indonesia.

Berdasarkan uraian tersebut di atas dapat disimpulkan bahwa Politik hukum lingkungan dalam UUD 1945 tidak diterjemahkan oleh semua produk hukum yang berkaitan dengan dengan pengendalian pencemaran B3 di wilayah laut yang berada dibawah kedaulatan Indonesia. Dengan demikian, terjadi inkonsistensi antara politik hukum lingkungan dalam UUD 1945 dengan politik hukum karena terdapat ketidaktetapan, ketidakselarasan, ketidaksesuaian, ketidakserasian, ketidakcocokan dan ketidakseimbangan antara politik hukum lingkungan dalam UUD 1945 dan politik hukum pengendalian pencemaran bahan berbahaya dan beracun di wilayah laut Indonesia.

Berdasarkan uraian tersebut di atas, dapat diambil kesimpulan bahwa adanya disharmonisasi secara horizontal antar produk nasional yang mengatur tentang pengendalian pencemaran B3 di wilayah laut yang berada dibawah kedaulatan Indonesia karena kesamaan pengaturan hanya terdapat dalam aspek hukum administrasi, sedangkan perbedaan pengaturan terdapat dalam aspek hukum perdata dan hukum pidana sehingga terjadi ketidakselarasan, ketidaksesuaian, ketidakserasian, ketidakcocokan dan ketidakseimbangan antar produk hukum tersebut.

\section{PENUTUP}

1. Kesimpulan

a. Kebijakan (policy) yang terdapat dalam instrument-instrumen tersebut yang mengatur pengendalian B3 antara lain pencegahan pencemaran B3 melalui larangan membuang 
limbah B3 ke dalam perairan, pengelolaan limbah yang berasal dari operasional kapal dan syarat-syaratnya serta tata cara pengangkutan B3 di perairan (meliputi: kriteria dan spesifikasi kapal pengangkut, perijinan, kuantitas B3 yang diangkut, pengemasan B3, pemberian lebel khusus B3, penyimpanan khusus B3, peralatan pendukung pengangkutan B3 dan pemberitahuan B3 yang diangkut ke negara tujuan atau transit) dan ketentuan-ketentuan pengendalian pencemaran B3 yang bersumber dari daratan, dasar laut, dumping dan kendaraan air (kapal).

b. UUPPLH dan PPPB3 mengatur aspek hukum administrasi, perdata dan pidana dalam upaya pengendalian pencemaran B3 di laut. UU Pelayaran hanya mengatur aspek hukum administrasi dan pidana, sedangkan aspek hukum perdata tidak di atur. UU Perairan menunjuk berlakunya hukum internasional dan peraturan perundang-undangan nasional. P5I hanya mengatur aspek hukum administrasi dan perdata, dan tidak mengatur aspek hukum pidana.

Hubungan antar produk hukum yang secara vertikal mengatur pengendalian pencemaran B3 di wilayah laut yang berada dibawah kedaulatan Indonesia, yaitu antara nilai-nilai pancasila, UUD N RI 1945 dan peraturan perundang-undangan nasional terjadi inkosistensi dan disharmonisasi karena tidak semua nilai pancasila dan pasal-pasal lingkungan dalam UUD $N$ RI 1945 direalisasikan dalam peraturan perundang-undangan yang mengatur pencemaran B3. Namun hubungan antar peraturan perundang-undangan secara horizontal itu sendiri terjadi inskonsistensi dan disharmonisasi karena tidak adanya ketidakselarasan, ketidaksesuaian, ketidakserasian, 
ketidakcocokan dan ketidakseimbangan antar peraturan perundang-undangan itu sendiri.

\section{SARAN}

a. Agar PPPB3 dan P5L yang masih merujuk pada undangundang pengelolaan lingkungan hidup yang lama, yaitu Undang-Undang Nomor 23 Tahun 1997 segera diganti peraturan pemerintah yang baru dengan merujuk pada undangundang perlindungan dan pengelolaan lingkungan hidup yang baru yaitu Undang-Undang Nomor 32 Tahun 1999.

b. Agar inkonsistensi dan disharmonisasi antar peraturan perundang-undangan yang mengatur pengendalian pencemaran B3 di wilayah laut segera dihilangkan dengan merevisi peraturan perundang-undangan tersebut.

\section{DAFTAR PUSTAKA}

Abdullah, Razali: Pancasila Sebagai Dasar Negara dan Pandangan Hidup Bangsa, Rajawali Pres, Jakarta, 1983.

Abdurrahman, Pengaantar Hukum Lingkungan Indonesia, Alumni, Bandung, 1983.

A.K., Syahmin, Beberapa Perkembangan dan Masalah Hukum Laut Internsional, Binacipta, Jakarta, 1985. 
Ashshofa, Burhan, Metode Penelitian Hukum, Rineka Cipta, Jakarta, 1996.

Azhary, Pancasila dan UUD 1945, Ghalia Indonesia, Jakarta, 1979.

Busro, Nilai dan Berbagai Aspeknya dalam Hukum, Bharata, Jakarta, 1989.

Daman, Rozikin, Pancasila Dasar Falsafah Negara, Rajawali Pers, Jakarta, 1992

Danusaputro, Munadjat, Hukum Lingkungan, Binacipta, Bandung, 1983.

Goesniadhie, Kusnu, Harmonisasi Hukum Dalam Perspektif PerundangUndangan, JP Books, Surabaya, 2006.

Hardjasoemantri, Koesnadi, Hukum Tata Lingkungan, Gadjah Mada University Press, Yogyakarta, 1990.

Hadjon, Philipus M, Penalaran Hukum (Legal Reasoning), Fakultas Hukum Universitas Airlangga, tanpa tahun.

Hartono, Sunaryati, Politik Hukum Menuju Satu Slstem Hukum Nasional, Alumni, Bandung, 1991.

Apakah Rule of Law itu? Bandung, Alumni, 1976.

Husin, Sukanda, Penegakan Hukum Lingkungan Indonesia, Sinar Grafika, Jakarta, 2009. 
Jaya, Nyoman Serikat Putera, Politik Hukum, Badan Penyediaan Bahan Kuliah Program Studi Magister Kenotariatan Universitas Diponegoro, Semarang, 2004.

Kantaatmadja, Bunga Rampai Hukum Lingkungan Laut Internasional, Alumni, Bandung, 1982.

Kusumaatmadja, Bunga Rampai Hukum Laut, Binacipta, Jakarta, 1985.

Koeswadji, Hermien Hadiati, Hukum Pidana lingkungan, Citra Aditya Bakti, 1993.

Latif, Abdul dan Ali, Hasbi, Politik Hukum, Sinar Grafika, Jakarta, 2011.

L. Tanya, Bernard, Politik Hukum (Agenda Kepentingan Bersama), Yogyakarta, Genta Publishing, 2009.

Mahfud MD, Moh, Politik Hukum di Indonesia, Rajawali Pers, Jakarta, 2010.

Mahmud Marzuki, Peter, Penelitian Hukum, Kencana, Jakarta, 2010,

Parthiana, Wayan, Pengantar Hukum Internasional, Mandar Maju, Bandung, 1990.

Prodjodikoro, Wirjono, Asas-Asas Hukum Pidana di Indonesia, Refika Aditama, Bandung, 2002

Rahardjo, Satjipto, Ilmu Hukum, Citra Aditya Bakti, Bandung, 1991. 
Rahmadi, Takdir, Hukum Lingkungan di Indonesia, Rajawali Pers, Jakarta 2011.

Hukum Pengelolaan Bahan Berbahaya dan Beracun, , Airlangga University Press, Surabaya, 2003.

Rangkuti, Siti Sundari, Hukum Lingkungan dan Kebijaksanaan Lingkungan Nasional, Airlangga University Press, Surabaya, 1996.

R.R. Churcil and A.V. Lowe, The Law of The Sea, Manchester University Press, Manchester, 1999.

Said Ali, As'ad, Negara Pancasila: Jalan Kemaslahatan Bangsa, LP3ES, Jakarta, 2009,

Setiardja, Gunawan, Filsafat pancasila Bagian I, BP Undip, Semarang, 2007.

Filsafat pancasila Bagian II, BP Undip, Semarang, 2007.

Siahaan, N.H.T., Ekologi Pembangunan dan Hukum Tata Lingkungan, Erlangga, Jakarta, 1987.

Soedarto, Hukum dan Hukum Pidana, Alumni, Bandung, 1986.

Soekanto, Soerjono, Pengantar Penelitian Hukum, UI Press, Jakarta, 1984. 
Soekanto, Soerjono dan Mamudji, Sri, Penelitian Hukum Normatif, Rajawali Pers, Jakarta, 2004.

Soemitro, Ronny Hanitijo, Metode Penelitian Hukum dan Jumitri, Ghalia Indonesia, Jakarta, 1990.

Suparni, Niniek, Pelestarian, Pengelolaan dan Penegakan Hukum Lingkungan, Sinar Grafika, Jakarta, 1994.

Syaukani, Imam dan Thohari, Ahsin, Dasar-Dasar Politik Hukum, Rajawali Pers, Jakarta, 2004.

Widjaja, H.A.W, Penerapan Nilai-Nilai Pancasila dan Hak Asasi Manusia di Indonesia, Rineka Cipta, Jakarta, 2000.

Winarno, Surachmad, Dasar dan Teknik Research Pengantar Metodologi IImiah, CV Tarsito, Bandung, 1970.

Konvensi Internasional dan Peraturan Perundang-Undangan Nasional

Konvensi Internasional Tentang Pencegahan Pencemaran dari Kapal Tahun 1973

Konvensi Internasional tentang Keselamatan Kehidupan Laut Tahun 1974

Konvensi Perserikatan Bangsa-Bangsa tentang Hukum Laut Internasional Tahun 1982 
Undang-Undang Nomor 12 Tahun 2011 tentang Pembentukan Peraturan Perundang-Undangan

Undang-Undang Nomor 32 Tahun 2009 tentang Perlindungan dan Pengelolaan Lingkungan Hidup

Undang-Undang Nomor 17 Tahun 2008 tentang Pelayaran

Undang-Undang Nomor 6 Tahun 1996 tentang Perairan IndonesiaPeraturan Pemerintah Nomor 74 Tahun 2001 tentang Pengelolaan Bahan Berbahaya dan Beracun

Peraturan Pemerintah Nomor 19 Tahun 1999 tentang pengendalian Pencemaran dan Perusakan Lingkungan laut 